\title{
A Spatial Analysis of Cultural Ecosystem Service Valuation by Regional Stakeholders in Florida-A Coastal Application of the Social Values for Ecosystem Services (SoIVES) Tool
}

\section{The Importance of the Coastal Zone and its Resources}

About half of our planet's human population lives near coastal areas (Crossland and others, 2005). As of 2010, in the continental United States, 44 percent of all land in urban areas, about 48,000 square miles, was within 25 miles of a coastline. About 12 percent of the Earth's surface pertains to the "coastal zone," described by Crossland and others (2005) as an area of intense interaction:

Here, land-dominated global processes and oceandominated global processes coalesce and interact, characterised by multiple biogeochemical environmental gradients. The balance of these interactions provides a unique domain of gradient-dependent ecosystems, climate, geomorphology, human habitation and, importantly, regimes of highly dynamic physical, chemical and biological processes (p. 1).

People living in coastal zones, and most of humanity, rely on marine and coastal systems for essential goods and services to maintain livelihoods and lifestyles. Shipping, energy production, and fishing are common examples of goods and services - stemming from marine and coastal spaces - that benefit humanity. The 2010 Deepwater Horizon explosion and subsequent oil spill is a vivid example of an event that compromised numerous goods and services of vital and immediate economic and social importance to residents of the Gulf of Mexico. The spill demonstrated that, while relatively few individuals are directly affected by oil spills, the stress of fishery closures that often follows quickly reverberates through communities and regional economies (Webler and Lord, 2010).

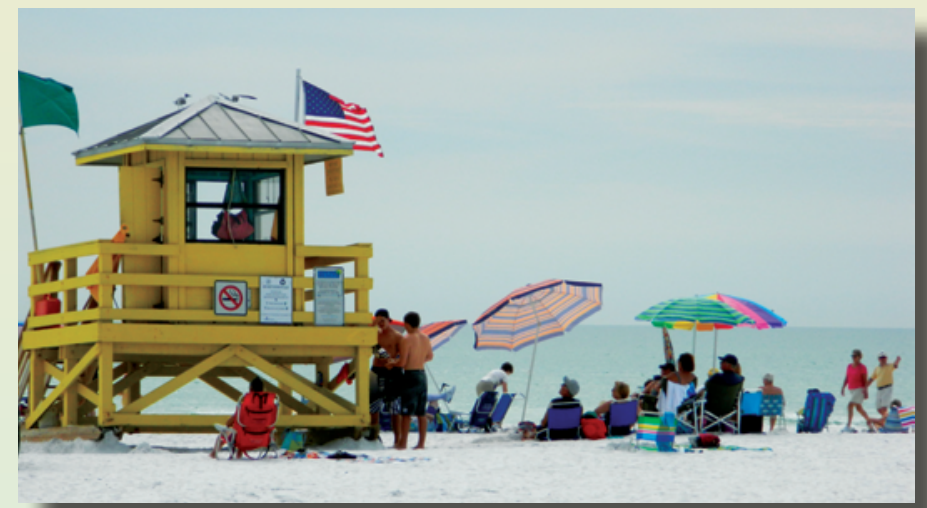

Beaches like this one in Siesta Key, Fla., are important coastal recreational spaces, drawing tourists and supporting local economies.

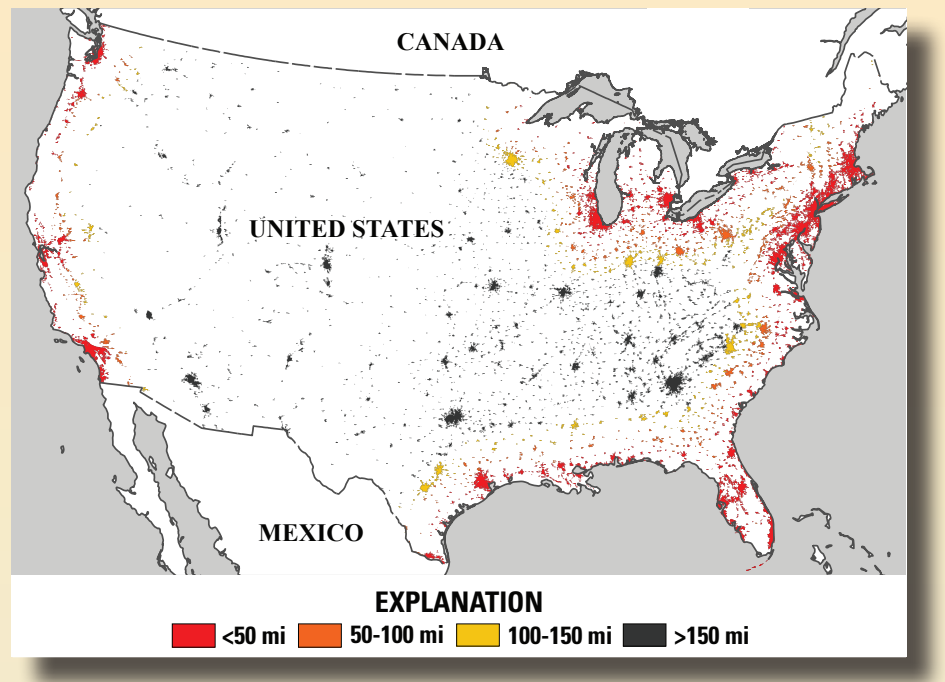

Urban areas of the continental United States, according to the 2010 U.S. Census. By area, about 69 percent of the urban land is within 150 miles of a coastline; of that area, about 65 percent is less than 25 miles from the coast.

Not all terrestrial, coastal, and marine spaces are the same. Rather, within them are differentiated systems with varying limits and opportunities to accommodate the use demands that we place on them (Foley and others, 2010). As demand for goods and services from marine and coastal spaces continues to grow, we find that competing, and often incompatible, uses vie for the same space. Increasingly, we also must contend with events and processes, such as oil spills and hypoxia, that diminish our ability to use coastal and marine spaces and have marked effects on the long-term prosperity of coastal communities and economically linked regions. The sustainability and resiliency of coastal communities depend on wise stewardship of coastal and marine spaces that considers how changes in physical and biological systems affect infrastructure, economies, and social well-being.

Coastal and marine spatial planning (CMSP) is a recent, science-based approach that is applied to marine and coastal spaces. CMSP builds on and extends traditional land use and regional planning efforts to provide for sustainable development to "reduce conflicts among uses, reduce environmental effects, facilitate compatible uses, and preserve critical ecosystem services to meet economic, environmental, security, and social objectives" (Halpern and others, 2012, p. 200). Importantly, CMSP considers the potential downstream effects of upland (terrestrial) uses on coastal and marine systems (Council on 
Environmental Quality, 2010). In recent decades, terrestrial, coastal, and marine planning efforts have adopted ecosystembased approaches. As exemplified in CMSP, such approaches seek to base human-use decisions on knowledge of the ecological limits of coastal and marine spaces and the ecosystem services that are provided.

\section{Coastal Ecosystem Services}

Ecosystem services are "contributions given by the environment that support, sustain and enrich human life" (Yoskowitz and others, 2010, p. 3). Marine and coastal spaces provide an array of ecosystem services that are critical to the resilience and sustainability of communities. For example, barrier islands and sand dunes provide protection from coastal storms by absorbing the brunt of wind and wave energy, thereby protecting valuable infrastructure from damage or destruction. Seagrasses are important nursery areas for marine life, providing fundamental economic support to the recreational boating and commercial and sport fishing industries (Rees and others, 2010). Vital economic services provided by ecosystems in the Gulf of Mexico region, for example, include off-shore energy extraction, shipping, tourism, and fishing (Sempier and others, 2009).

Increasingly, environmental planners and managers responsible for guiding decision alternatives or evaluating costs of damage seek to assign a common metric, such as a dollar value, to the various goods and services provisioned by the environment. Ecosystem service valuation research seeks to ascribe value to the services provided by ecosystems with the intent of providing a measure that allows us to compare economic costs and benefits of management decisions or damages from natural or anthropogenic disasters.

Economic value is the most common metric in use, but many ecosystem services do not readily lend themselves to monetization. Individuals do not always think in monetary terms when assigning value to an environmental benefit or service, particularly those that are cultural (Daniel and others, 2012). Cultural ecosystem services are defined by the Millennium Ecosystem Assessment as, "non-material benefits people obtain from ecosystems through spiritual enrichment, cognitive development, reflection, recreation, and aesthetic experience...." (2005, p. 209). For example, many people value the aesthetic and recreational opportunities provided by clear sparkling waters and white sandy beaches free of debris and contaminants. While it is important to understand the economic value of coastal ecosystems, decisions made by people who use coastal and marine spaces are based on an array of factors that include both economic and cultural concerns.

To plan for the sustainable use of coastal areas, as recommended by CMSP methods, it is important to know the current

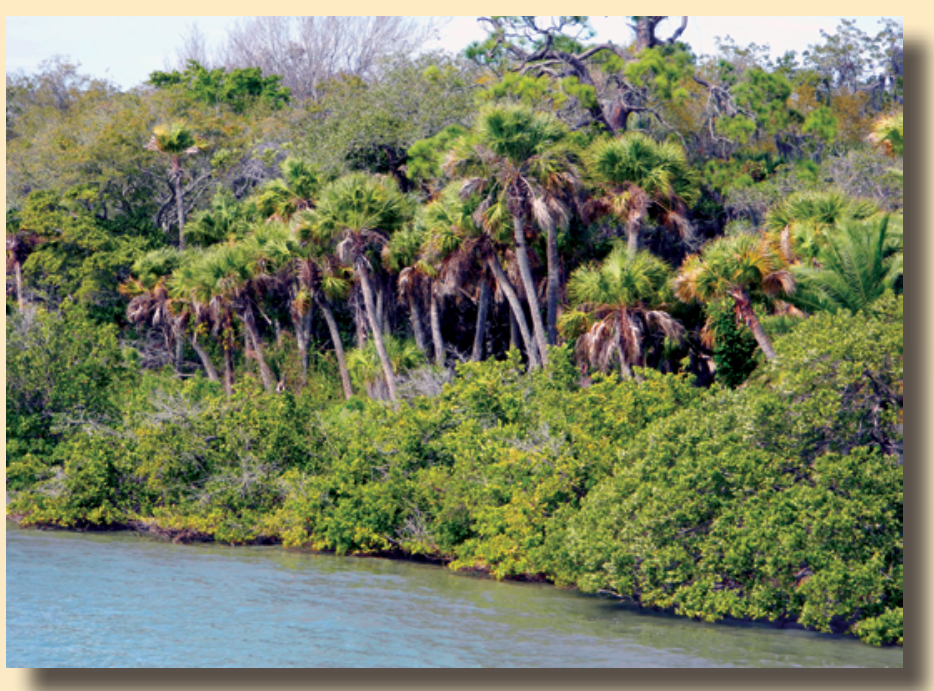

Mangroves on the shoreline of Sarasota Bay. The native mangrove and palm trees provide important services, including protection from erosion by wave action and habitat for animals that live near the shore.

state of environmental resources and how they are valued. Coastal resource managers use spatial information about coastal environments to plan for their sustainable use. Accurate geographic data about the environment, including what areas people use and for which uses, are essential for this task. The mapping and analysis of physical and biological systems in coastal zones has been evolving for decades. While new technologies, such as radar imaging, offer cost-effective methods for collecting higher quality data about the physical environment, there are gaps in our knowledge of how coastal residents and users value these resources. Furthermore, although it is critical to the development of ecosystem-based, coastal-use plans, the availability of this type of information for marine environments is rare as compared to that available for terrestrial environments.

\section{Project Overview}

A basic goal of this research is to close gaps in our knowledge about the attitudes and perceptions, or nonmonetary values, held by coastal residents for ecosystem services, particularly for cultural services. Another important project goal is to adapt terrestrial-based research methods to a coastal setting. Finally, a critical goal is to integrate research results with coastal and marine spatial planning applications, thus making them relevant to coastal planners and managers in their daily efforts to sustainably manage coastal resources.

To accomplish these goals, researchers from the U.S. Geological Survey (USGS) are working collaboratively with partners from the Florida Sea Grant College Program, a National Oceanic and Atmospheric Administration (NOAA)- and state 
of Florida-funded program, and the University of Florida. Together, we are mapping the nonmonetary values of cultural ecosystem services for a pilot area in the Gulf of Mexico, a region that was selected as a high priority for ecosystem services research and coastal and marine spatial planning applications (Sempier and others, 2009; Council on Environmental Quality, 2010; Yoskowitz and others, 2010; Plantier-Santos and others, 2012).

The project area is the Sarasota Bay lagoon and embayment system and nearby offshore environment, located on the Florida Gulf Coast. Local residents and visitors derive numerous economic and nonmonetary benefits from this rich, coastal lagoon system. The "Bay" is a discrete area stretching about 56 miles along the coast, with its center in Sarasota Bay. The project area has a population of about 600,000 people living in the 455-square-mile watershed (Sarasota Bay Estuary Program, 2011) and the cities, beach communities, and suburbs of this region are home to vibrant urban neighborhoods and an active citizenry, concerned with the future of their environment. Unlike an undeveloped, protected area under the management of one agency, the numerous stakeholders in this area are engaged in the challenge of working together to balance land and coastal uses that are sometimes at odds with each other. These characteristics make Sarasota Bay an excellent place to evaluate methods for quantifying the nonmonetary values of ecosystem services in a coastal environment.

Over the last several years, the USGS has developed methods to "assess, map, and quantify social values for ecosystem services" (Sherrouse and others, 2011). These methods were integrated in a geographic information system (GIS) tool, Social Values for Ecosystem Services, version 2.0 (SolVES, 2.0; $\mathrm{http}$ :// solves.cr.usgs.gov). Using information about the attitudes and preferences of people toward places and uses in the landscape, collected from value and preference surveys, SolVES 2.0 provides quantitative models to relate social values, or perceived nonmonetary values, assigned to locations by survey respondents with the underlying environmental characteristics of those same locations.

The work to adapt SolVES 2.0 for use in a coastal environment is performed in phases, or steps. The first two steps were completed in early 2012, with work progressing on subsequent steps. The first step required the validation and adaptation of the underlying "values typology," the framework that informs the values allocation process in SolVES, to a coastal environment. The second step involved the collection of data in the study area via an online survey developed by the University of Florida and Florida Sea Grant, based on regional stakeholder priorities and recommendations. Data collection was restricted to the northern half of Sarasota Bay, while the southern half was reserved for model testing and validation. The third step integrates the survey data in the SolVES tool, creates environmental datasets for analysis, and develops quantitative value-transfer models. In the fourth step, the models will be tested in the southern half of Sarasota Bay. Data collected in earlier Florida Sea Grant studies will be used to validate model results and improve their predictive capabilities.

Ultimately, our goal is to integrate these methods with CMSP principles and procedures and to adapt this research to the needs of decision makers in coastal areas. In the final phase of this project, we will work with groups and individuals from

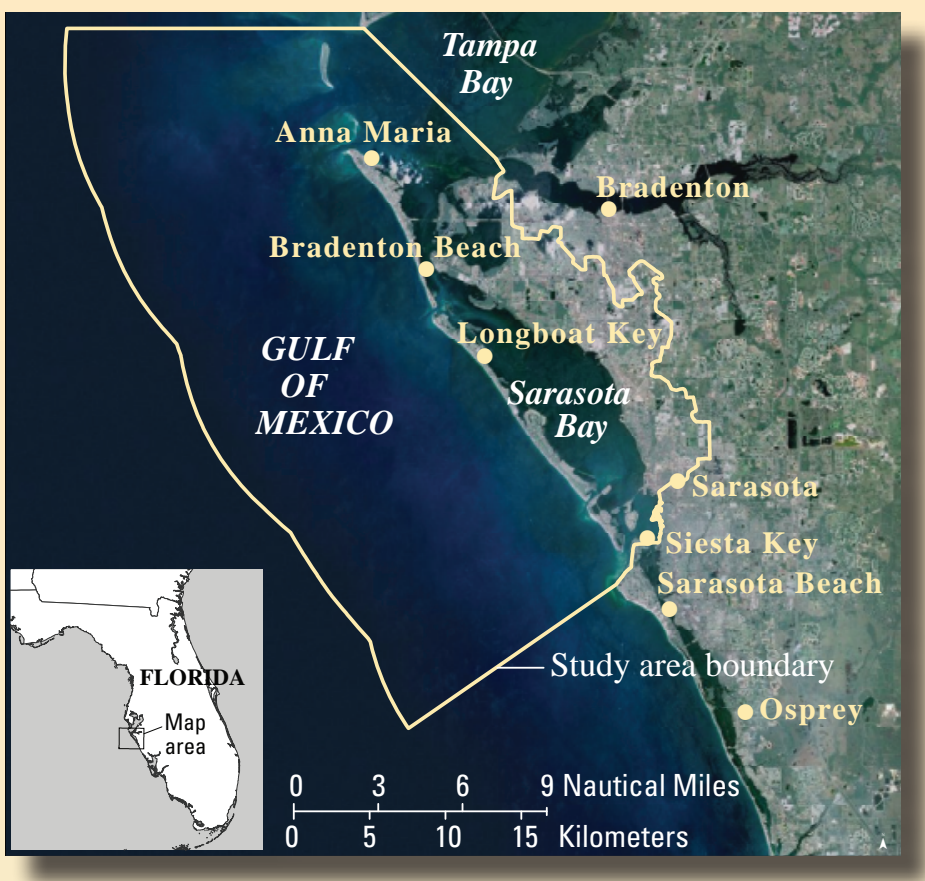

Greater Sarasota Bay region. Base map from World Imagery by Esri, Inc., 2012, 1:400,000.

various local and regional agencies to closely examine the data for information relevant to their needs.

We anticipate that project results will increase scientific and geographic knowledge of how Sarasota Bay residents value their area's cultural ecosystem services. Also, the quantitative spatial models resulting from this research will allow us to extend analyses beyond the study area and predict how similar resources may be valued in other locations. This research contributes to our understanding of how perceptions, knowledge, and values of ecosystem services drive individual and collective decisions and actions that affect Gulf of Mexico coastal economies and resiliency. Finally, because a critical goal of this research is to translate the scientific results into information that can be used in CMSP applications, we will work with interested stakeholders in the region to formulate a product that can benefit the sustainable management of coastal resources.

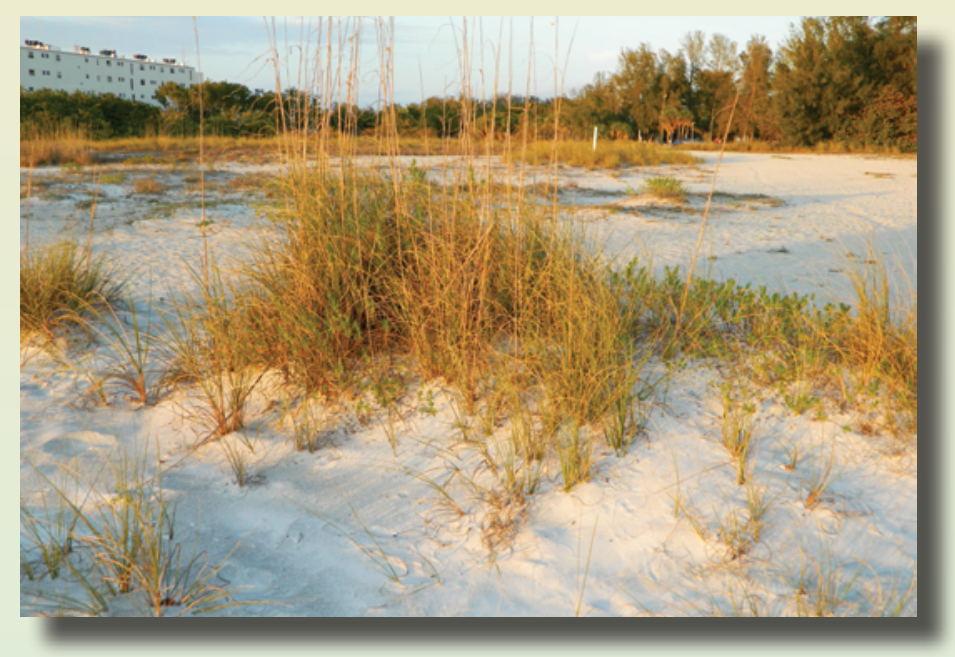

Dune grasses are critical for maintaining habitat quality. These plants offer important ecosystem services, including protecting sandy beaches from erosion and providing habitat for birds and other shoredwelling animals. 


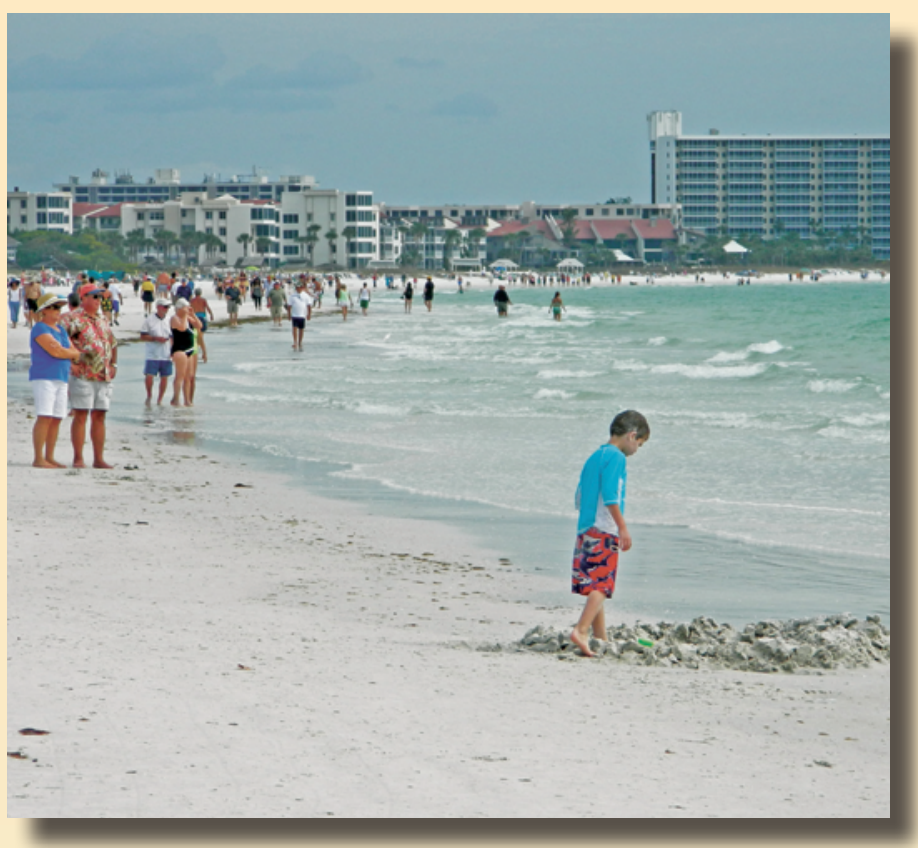

Coastal Florida is highly developed in many places. In this photo, residential and recreational uses coincide in Sarasota County.

\section{References Cited}

Council on Environmental Quality, 2010, Final recommendations of the interagency Ocean Policy Task Force, July 19, 2010: Washington, D.C., Executive Office of the President of the United States, available at $h t t p: / / w w w . w h i t e h o u s e . g o v / a d m i n i s t r a t i o n / e o p / c e q /$ initiatives/oceans/.

Crossland, C.J., Baird, D., Ducrotoy, J.P., and Lindenboom, H.J., 2005, The coastal zone-A domain of global interactions, in Crossland, C.J., and others, eds., Coastal fluxes in the Anthropocene-The land-ocean interactions in the coastal zone project of the International Geosphere-Biosphere Programme (Global change-The IGBP series): Berlin, Germany, Springer-Verlag, p. 1-38.

Daniel, T.C., Muhar, A., Arnberger, A., Aznar, O., Boyd, J.W., Chan, K.M.A., Costanza, R., Elmqvist, T., Flint, C.G., Gobster, P.H., Grêt-Regamey, A., Lave, R., Muhar, S., Penker, M., Ribe, R.G., Schauppenlehner, T., Sikor, T., Soloviy, I., Spierenburg, M., Taczanowska, K., Tam, J., and von der Dunk, A., 2012, Contributions of cultural services to the ecosystem services agenda: Proceedings of the National Academy of Sciences of the United States of America, v. 109 , no. 23 , p. $8,812-8,819$.
Foley, M.M., Halpern, B.S., Micheli, F., Armsby, M.H., Caldwell, M.R., Crain, C.M., Prahler, E., Rohr, N., Sivas, D., Beck, M.W., Carr, M.H., Crowder, L.B., Duffy, J.E., Hacker, S.D., McLeod, K.L., Palumbi, S.R., Peterson, C.H., Regan, H.M., Ruckelshaus, M.H., Sandifer, P.A., and Steneck, R.S., 2010, Guiding ecological principles for marine spatial planning: Marine Policy, v. 34, no. 6, p. $955-966$.

Halpern, B.S., Diamond, J., Gaines, S., Gelcich, S., Gleason, M., Jennings, S., Lester, S., Mace, A., McCook, L., McLeod, K., Napoli, N., Rawson, K., Rice, J., Rosenberg, A., Ruckelshaus, M., Saier, B., Sandifer, P., Sholtz, A., and Zivian, A., 2012, Near-term priorities for the science, policy and practice of coastal and marine spatial planning (CMSP): Marine Policy, v. 36, no. 1, p. 198-205.

Millennium Ecosystem Assessment, 2005, Ecosystems and human well-being - A framework for assessment: Washington, D.C., World Resources Institute.

Plantier-Santos, Carlota, Carollo, C., and Yoskowitz, D.W., 2012, Gulf of Mexico ecosystem service valuation database (GecoServ) Gathering ecosystem services valuation studies to promote their inclusion in the decision-making process: Marine Policy, v. 36, no. 1, p. 214-217.

Rees, S.E., Rodwell, L.D., Attrill, M.J., Austen, M.C., and Mangi, S.C., 2010, The value of marine biodiversity to the leisure and recreation industry and its application to marine spatial planning: Marine Policy, v. 34, no. 5, p. 868-875.

Sarasota Bay Estuary Program, 2011, The Bay: Sarasota Bay Estuary Program, available at http://sarasotabay.org/.

Sempier, S.H., Havens, K., Stickney, R., Wilson, C., and Swann, D.L., 2009, Gulf of Mexico Research Plan, Report No. MASGP09-024: Gulf of Mexico Sea Grant Programs, available at http:// gulfseagrant.tamu.edu/.

Sherrouse, B.C., Clement, J.M., and Semmens, D.J., 2011, A GIS application for assessing, mapping, and quantifying the social values of ecosystem services: Applied Geography v. 31, no. 2, p. $748-760$.

Webler, Thomas, and Lord, Fabienne, 2010, Planning for the human dimensions of oil spills and spill response: Environmental Management, v. 45 , no. 4, p. 723-738.

Yoskowitz, D.W., Santos, C., Allee, B., Carollo, C., Hendersen, J., Jordan, S.J., and Ritchie, J., 2010, Proceedings of the Gulf of Mexico Ecosystem Services Workshop, Bay St. Louis, Miss., June 16-18, 2010: Harte Research Institute for Gulf of Mexico Studies, Texas A\&M University - Corpus Christi, 16 p.

\section{For Further Information Contact}

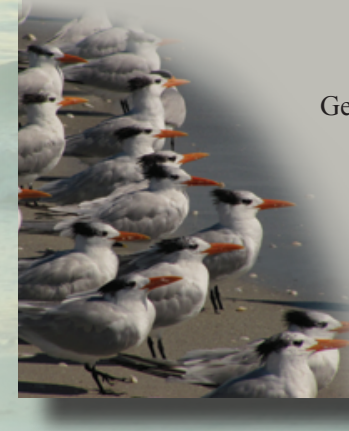

Alisa W. Coffin, Ph.D.

Geosciences and Environmental

Change Science Center

U.S. Geological Survey

2150 Centre Ave. Bldg. C

Fort Collins, CO 80526

(970) 226-9480

alisa_coffin@usgs.gov
Robert A. Swett, Ph.D.

School of Forest Resources and Conservation

University of Florida PO Box 110760

Gainesville, FL 32611 (352) 392-6233 rswett@ufl.edu
Zachary D. Cole, Ph.D.

Department of Tourism, Recreation, and Sport Management University of Florida PO Box 118208

Gainesville, FL 32611 (352) 294-1683 zaccole@hhp.ufl.edu

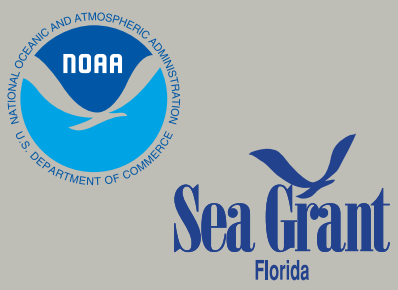

SGEF-199

UF
IFAS

UNIVERSITY of FLORIDA 